\title{
Forest influence on flash floods in small streams
}

\section{PAVOL MIKLANEK, PAVLA PEKAROVA, DANA HALMOVA \& ALES SVOBODA}

Institute of Hydrology, Slovak Academy of Sciences, Racianska 75, 83102 Bratislava 3, Slovak Republic miklanek@uh.savba.sk

\section{INTRODUCTION}

The description and post-event analysis of catastrophic flood events using rainfall-runoff models are extremely important for management of flood risk and evaluation of flood design values (Gaume et al. 2009). We describe efforts in reconstruction of flood peak flows according to the measured cross-sections, longitudinal slopes and roughness coefficients, and also results achieved by rainfall-runoff modelling of the flood hydrographs.

\section{DATA AND METHODS}

Two selected documented extreme floods on small forested streams in Slovakia (Table 1, Fig. 1(a)) are compared: 1. flood on 20 July 1998, on the Mala Svinka River at Jarovnice (34.39 $\mathrm{km}^{2}$ ), ungauged catchment; 2. floods on 7 June 2011 in the Lesser Carpathians: on Gidra Creek at Pila station $\left(32.954 \mathrm{~km}^{2}\right)$ and on Parna Creek at Horne Oresany station $\left(37.86 \mathrm{~km}^{2}\right)$, gauged catchments (Svoboda et al. 1998, Pekarova et al. 2012).

Table 1 Basic physico-geographic characteristics of the selected catchments: A - catchment area, L - length of the valley, Qa - mean annual discharge, I - slope, P - rainfall depth during the flood, Td - rainfall duration during the flood, Qmax - peak specific yield during the flood, $\mathrm{Kr}$ - runoff coefficient of the flood wave.

\begin{tabular}{llllllllll}
\hline Stream - station & $\begin{array}{l}\mathrm{A} \\
\left(\mathrm{km}^{2}\right)\end{array}$ & $\begin{array}{l}\mathrm{L} \\
(\mathrm{km})\end{array}$ & $\begin{array}{l}\text { Qa } \\
\left(\mathrm{m}^{3} \mathrm{~s}^{-1}\right)\end{array}$ & $\begin{array}{l}\text { Forest } \\
(\%)\end{array}$ & $\mathrm{I}$ & $\begin{array}{l}\mathrm{P} \\
(\mathrm{mm})\end{array}$ & $\begin{array}{l}\mathrm{Td} \\
(\mathrm{h})\end{array}$ & $\begin{array}{l}\text { Qmax } \\
\left(\mathrm{m}^{3} \mathrm{~s}^{-1} \mathrm{~km}^{-2}\right)\end{array}$ & $\mathrm{Kr}$ \\
\hline 1. Mala Svinka: & 34.39 & 13.8 & - & 50 & & 80 & 1.5 & 5.19 & 0.68 \\
2a. Gidra: Pila & 32.95 & 7.9 & 0.28 & 97 & 9.93 & 95 & 3.5 & 1.36 & 0.16 \\
2b. Parna: Majdan & 37.86 & 11.0 & 0.35 & 98 & 11.7 & 80 & 3.5 & 1.61 & 0.22 \\
\hline
\end{tabular}

For rainfall-runoff simulation we used a simple mathematical model: NLC (Non Linear Cascade). It is a conceptual lumped model consisting of storage (linear and nonlinear) elements. Its description can be found in more detail in Svoboda (1987). NLC represents a simple, twocomponent, rainfall-runoff model capable of modelling groundwater flow and direct runoff. It is of a lumped type, input into the model is total rainfall over the catchment in each time interval. The schematic model structure is shown in Fig. 1(b).

(a)

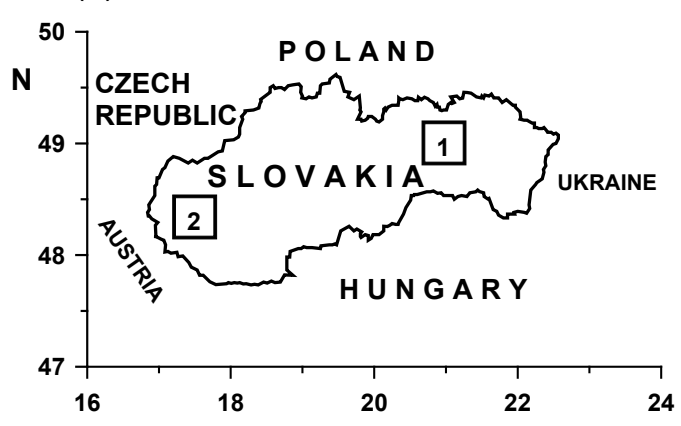

(b)

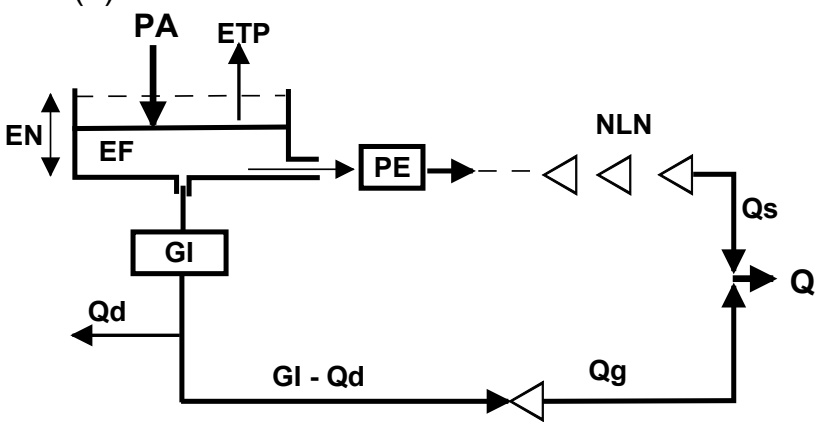

Fig. 1 (a) Location of the catchments. (b) Schematic of the NLC model structure. 


\section{RESULTS}

Examples of simulated discharge during the selected floods are shown in Fig. 2. It is important to take into account that these catchments are situated in different geographical regions and the floods originated from different rainfall events. In spite of that, the comparison allows us to note some important aspects, for example the extremely high peak specific runoff in Mala Svinka catchment was produced by the rainfall event of the shortest duration $(\sim 1.5$ hour $)$ in flysh geological formation. The runoff volume of the flood event at Jarovnice was $68 \%$ of the rainfall (Table 1). The low runoff coefficient of the flood in the Lesser Carpathians is another surprising fact. It illustrates the very good drainage and water retention properties of the karstic catchments. Despite this, the flash flood in the Lesser Carpathians had catastrophic consequences in villages such as Dolany, Casta and Horne Oresany, and in Pila village in particular.
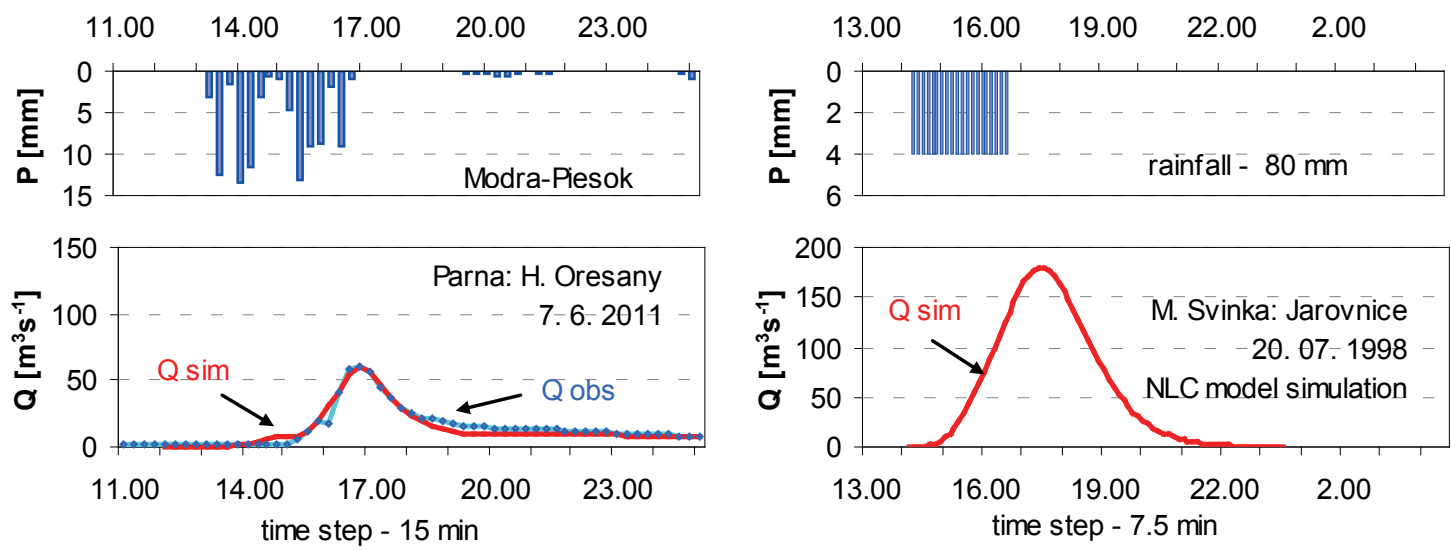

Fig. 2 Measured and simulated flood discharge in Parna and Svinka catchments.

\section{DISCUSSION}

It is supposed that the presented results would supply additional data on rare events needed for the development and use of regional formulae for peak flow estimates in structural design. They also indicate that the primary cause of such events is the relevant precipitation together with the initial soil moisture conditions in the catchment, contrary to some recently popular statements attributing them to the anthropogenic interventions into the vegetation cover and to the river channel regulation. An intensive rainfall over a small catchment sufficiently wetted by the antecedent even moderate precipitation, can cause a disastrous flood which cannot be effectively reduced neither by retention capacity of the shallow soil, nor by interception of a dense and healthy forest. The results also indicate a need for revision of our views upon the use of regional formulae in general, and upon the meaning of the "design peak flow" in particular.

Acknowledgement This work was supported by the Science and Technology Assistance Agency under contract No. APVT-0015-10 during the project implementation "the Centre of excellence for integrated flood protection of land" (ITMS 26240120004) supported by the Research \& Development Operational Programme funded by the ERDF.

\section{REFERENCES}

Gaume, E., et al. (2009) A compilation of data on European flash floods. J. Hydrol. 367, 70-78. doi:10.1016/ j.jhydrol.2008.12.028.

Pekarova, P., et al. (2012) Estimating flash flood peak discharge in Gidra and Parná basin: case study for the 7-8 June 2011 flood. J. Hydrol. Hydromech., 60(3), 206-216.

Svoboda, A. (1987) Two-component nonlinear rainfall-runoff model NLC. J. Hydrol. Hydromech., 35(6), 661-663 (in Slovak).

Svoboda, A. and Pekarova, P. (1998) The catastrophic flood of July 1998 in the Mala Svinka catchment - its simulation. J. Hydrol. Hydromech. 46(6), 356-365 (in Slovak). 